\title{
The Design of Curriculum Development Based on Entrepreneurship through Balanced Scorecard Approach
}

\author{
Muhammad Hidayat ${ }^{1}$, Chalid Imran Musa ${ }^{1}$, Siti Haerani $^{2} \&$ Indrianti Sudirman $^{2}$ \\ ${ }^{1}$ Department of Economics, Universitas Negeri Makassar, Indonesia \\ ${ }^{2}$ Department of Economics, Universitas Hasanuddin, Indonesia \\ Correspondence: Muhammad Hidayat, Department of Economics, Universitas Negeri Makassar, Indonesia. \\ E-mail: hidayat2401@yahoo.com
}

Received: July 3, 2015 Accepted: August 14, 2015 Online Published: October 28, 2015

doi:10.5539/ies.v8n11p123 URL: http://dx.doi.org/10.5539/ies.v8n11p123

\begin{abstract}
This research is intended to develop curriculum based on entrepreneurship through balanced scorecard approach at the School of Business or Sekolah Tinggi Ilmu Ekonomi (STIE) Nobel Indonesia. In order to develop the curriculum, a need analysis in terms of curriculum development that involves all stakeholders at STIE Nobel in Indonesia has been conducted. This research found that the basic skills of entrepreneurship are the main data in the curriculum development based on entrepreneurship. The researchers classify those skills into four business perspectives in accordance with the principle of the balanced scorecard. This study showed that the balanced scorecard approach can be used as a means of mapping the curriculum and the theme for teaching entrepreneurship at STIE Nobel Indonesia.
\end{abstract}

Keywords: curriculum development, entrepreneurship subject, balanced scorecard approach, teaching strategy

\section{Introduction}

Educational institutions today face increasingly complex challenges in line with increasing global competition, rapid development, use of technology, lack of resources and education paradigm shift from the more enlightened society. Estuary of various complex issues is the need to create high-quality education. Thus, the output of the implementation of education is an intellectual who has the mental and spiritual ability to respond to all challenges not only for individual challenges, but also for regional, national and global challenges.

There are three main reasons which caused the number of graduates who are not working, namely cultural barriers, the quality of the university, and the relevance of the educational curriculum with the labor market Tilaar (2002). One of the obstacles related to the number of alumni who are not worked is the relevance of the curriculum. Thus, each institution of higher education requires appropriate strategies in developing the curriculum, especially for construction, implementation, and evaluation of the curriculum. It is an attempt to create graduates who actually have competence in responding various challenges, both internal and external challenges that come from the environment.

In order to answer those challenges as mentioned above, researchers through this research propose the use of a balanced scorecard approach based on entrepreneurship as a strategy for curriculum development in universities by taking a case study at STIE Nobel Indonesia. The balanced scorecard based on entrepreneurship is a strategy to map curriculum in-depth analysis of the needs of curriculum development, formulation, implementation, and strategies to lecture. In this case, the principle of balanced scorecard used as a perspective on how an entrepreneur should manage its business with a consideration that the balanced scorecard can be used as a tool in the preparation of a strategy to direct the organization to be able in achieving the predetermined goal. Therefore, an entrepreneur must have a clear understanding of the four business perspectives, namely (1) financial perspective, (2) customer perspective, (3) internal business process perspective, and (4) learning and growth perspective in the implementation of its business. Those perspectives can help an entrepreneur to develop the right strategy and measure it by using an appropriate measuring instrument. The theme of the balanced scorecard in curriculum development is expected to produce appropriate learning formulation through learning at critical phases in four business perspectives that should be understood by every person who is oriented to be an entrepreneur. 
The formulation of this research is intended to answer the following research questions.

- How is the design of curriculum development based on entrepreneurship in STIE Nobel Indonesia if the balanced scorecard approach is used as a strategic tool for curriculum mapping in curriculum development?

- How are the stages of teaching entrepreneurship subjects after the curriculum mapping conducted by using a balanced scorecard approach?

\section{Review of Related Literature}

\subsection{Strategic Planning}

The strategic planning process is an important factor for any organization to achieve its vision and mission. In this process, some approaches are performed. One of them is to understand the position of the organization with other similar organizations. Hence, a further strategic approach that is beneficial and efficient for the organization through an understanding of the position will be obtained (Nayeri et al., 2008).

David (2009) states "strategy is the art of making the formulation, implementation and evaluation of decisions that direct the organization to achieve its intended purpose." In addition, (Porter, 1996) in his article entitled "What Is Strategy" states: "strategy is the creation of a unique and valued position, involving a different set of activities." (Chandler, 1962) in his book entitled "Strategy and Structure" defines strategy as "the determination of the long-term goals and objectives of an enterprise, and the adoption of courses of action and the allocation of resources necessary for carrying out the goals."

Based on the definitions above, the strategy can be mentioned as a step taken by the organization in utilizing all its resources devoted to create a position for the organization by displaying unique features as advantages possessed by the organization. Thus, if it is referred to the strategic planning at a university, it can be directed to perform positioning by showing the advantages and peculiarities of a university compared with other similar universities. One of the advantages is the curriculum offered by universities to the community.

\subsection{Balanced As an Approach in Teaching Strategy of Entrepreneurship}

The balanced scorecard was first proposed by Kaplan and Norton in the Harvard Business Review in 1992 as a comprehensive performance measurement tool that views the performance of the organization including performance on financial and non-financial perspective. Through the balanced scorecard, performance is not only seen on the achievement of performance at this time but also prepares measures of performance in the future. During its development, the balanced scorecard does not only serve as a performance measurement tool, but also becomes a comprehensive management (Kaplan \& Norton, 2001; Niven 2002). This approach emphasizes that the strategies developed by the organization must be derived from a comprehensive idea. It not only focuses on the outcome, but also considers the process undertaken by the organization. As a strategic management tool, the balanced scorecard can be used to align the vision, mission, and values of company into operational terms that are arranged such a manner to be information and motivation as an effort to make continual improvements (Hoffeker, 1994; Kaplan \& Norton,1992, 1996, 2001; Maisel, 1992; Newing 1994, 1995).

In a balanced scorecard approach, organizational performance is viewed through four business perspectives, namely (1) financial perspective, (2) customer perspective, (3) internal business process perspective, and (4) learning and growth perspective in the implementation of its business. These business perspectives are interrelated in the sequence of causal interactions with one another (Kaplan, 2001). In the context of the balanced scorecard, the balance in the interaction among the four perspectives will determine the success of an organization in the process to achieve the vision and mission of the organization.

Recognition for the balanced scorecard as a comprehensive strategic approach has prompted several researchers to conduct research and propose this approach as a performance measurement tool and strategic tool at universities (Ruben, 1999; Karathanos, 2005; Umashankar, 2007; Beard, 2010; Chen et al., 2012; Indriyanti, 2012; Rompho, 2012). In its application to the universities, the balanced scorecard is applied to adjust the goals and needs of the organization. Moreover, it can be applied to certain parts of the universities (Rompo, 2012; Afshari et al., 2012), including to develop a curriculum (Sherman, 2007; Fletcher, 2007)

The balanced scorecard as a theme in teaching entrepreneurship in the university is based on the idea that it has mapped four business perspectives that will deliver an organization's success. Thus, it is an important input for education, especially in teaching entrepreneurship to teach the four perspectives of the business in the lecture system. Hence, students will master the ways of managing the four business perspectives better than ever since the lectures process. 
The necessity of the use of the balanced scorecard as a tool for curriculum development has been conducted by (Sherman, 2011). He conducted research related to the use of a balanced scorecard as integrated curriculum themes in Saint Joseph's University. In this study, he suggested some economic education courses that would be taught at Saint Joseph's University. Moreover, he attributed integrative relationships between each of the subjects in the concept of the balanced scorecard. A similar study was also conducted by (Smith and Fletcher, 2007). They conducted their research in the Executive MBA Loyola College. In their study, they propose teaching using the balanced scorecard in the MBA curriculum system in the Executive MBA Loyola College

In general, the balanced scorecard approach is used as a strategic approach to curriculum development in research of (Sherman, 2011) and (Fltcher, 2007). This idea is used to show that a professional in the business that comes from an educational institution will eventually be faced with the real business where the management of the business will require the right strategy that will take him to achieve the expected business goals. The empirical fact shows that the balanced scorecard is a comprehensive approach that has been proven successfully applied by the business world. Therefore, it is crucial if a professional must understand the business perspectives appropriately and correctly. It can be performed by understanding them through a scientific and practical approach to learning programs that are packed in an integrated curriculum. The curriculum should be implemented by the university that has vision and mission in the theme of the business.

The use of a balanced scorecard as a theme in the curriculum also has a relevant basis. The business perspectives in the balanced scorecard can be detailed through the subjects, which are generally taught in the universities. Financial perspective can be detailed into subjects related to the problems of financial management. Customer perspective can be detailed with the subjects that discuss marketing, service, and partnership problems in terms of quality. The internal business process perspective can be detailed through the subjects that discuss production problems, operational problems and other problems that support organizational process. Learning and growth perspective can be detailed through basic subjects on the issues of the use of technology, human resource, and issues relating to development. Hence, the use of a balanced scorecard approach as a tool to analyze the needs and as the theme of the composition of the curriculum is expected to produce an integrated curriculum that is appropriate to the needs of the business world in the field.

\subsection{Curriculum Design Based on Entrepreneurship}

Need analysis in curriculum development is the first step that is a very important in developing and designing the curriculum. Curriculum development models that have existed show the importance of need analysis. Therefore, the curriculum can be structured to achieve the predetermined goal. The need for conducting a situational analysis is fundamental precept of effective curriculum development. Developer commencing their task should be an important question such as what do we know about the context the students, teacher, school environment of this curriculum and why is it need. This provided then with information-based to pose an even more fundamental question what do our learners need? a recommended approach to conduct situational analysis involves four steps namely: 1) identify problem 2) select approach factors 3) data collection and analysis 4) make recommendation (Nicholls \& Nicholls, 1974) cited by (Hussain, Dogar, Azeem, \& Shakoor, 2011). Those steps can be described as follows.

- The first step is identifying the problems that are faced by business world by asking the important things related to the problem to entrepreneurs.

- The second step is using an appropriate approach. Therefore, the identification that has been conducted can produce the right data related to the problem of the business and its solution. In this study, the approach that is used in this analysis is the balanced scorecard approach. It aims at observing the business problem from four perspectives, namely financial, customer, internal business process, and learning and growth.

- The third step is data collection. The data were collected and analyzed in such a way in accordance with the main objective, namely, to build and develop the curriculum.

- The fourth step is providing recommendations based on the needs analysis of curriculum development that have been conducted. In this study, the resulting recommendation is the design of curriculum development based on entrepreneurship through the balanced scorecard approach.

These are the steps for the needs analysis within the scope of curriculum development. They become the external factors that can affect the internal components of an existing curriculum. Taba model as cited by (Hussain et al., 2011) describes these external factors as described in the Figure 1 as follows: 


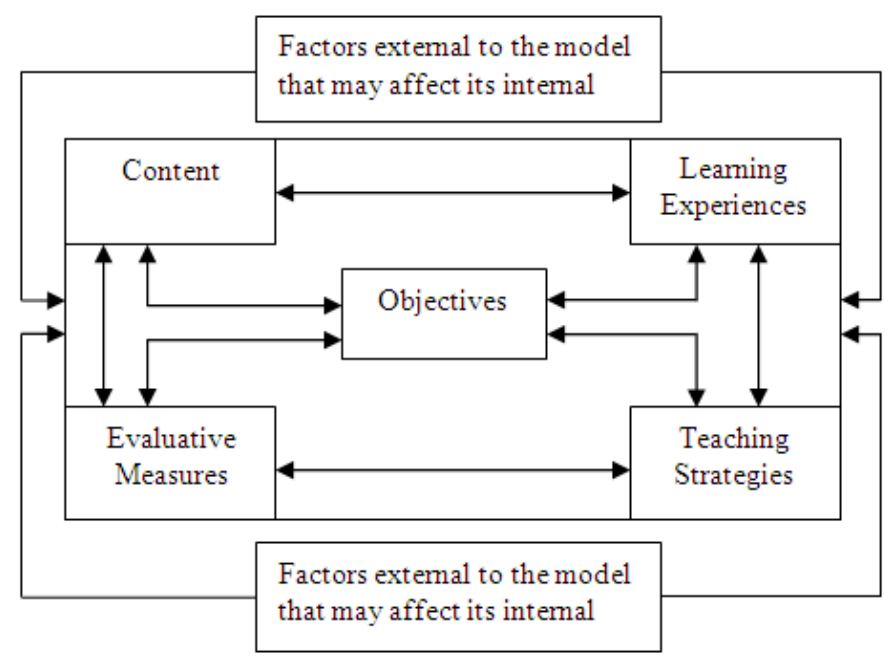

Figure 1. Designing the curriculum an instructional strategies approach from Hilda Taba

In this study, the analysis of external factors is conducted using the balanced scorecard approach. In addition, the other five components, namely teaching strategies, learning experiences, content, evaluative measures and objectives are also mapped using the balanced scorecard approach

\section{Method}

This research was a qualitative research. It was conducted by using Research and Development approach. The data were collected through field observation by performing observation and recording activities systematically of the investigated phenomena mainly related to the teaching and the learning process in the sphere of entrepreneurship lectures in STIE Nobel Indonesia. Through this observation, the researchers also observed various entrepreneurial practices where these practices are the student activities within the scope of the assignment of lectures. Through this observation, the researchers also conducted direct observations in the lectures process in STIE Nobel Indonesia to find out method and system used by the lecturers within the scope of entrepreneurship subjects. Data collection was also conducted by interviewing respondents who were divided into four groups according to the concept of the balanced scorecard. The first group was twenty-one entrepreneurs in Makassar. The second group was fifty-four students in STIE Nobel Indonesia. The third group was the lecturer of entrepreneurship subject. The four groups was the manager of STIE Nobel Indonesia. In addition, the data were obtained through documentation. The documentation was the collection of documents related to the curriculum used by STIE Nobel Indonesia, including documentation of the data in the study, particularly the documentation of the important files that support this research. There was also Focus Group Discussion (FGD). It is an activity to undertake in-depth discussion followed by all concerned parties to discuss the data found during the study. This forum was also intended to look at trends, similarities, differences of the participants in viewing a phenomenon. In this study, there have been conducted focus group discussions involving managers, lecturers, the chairman of the institution, and the staff and employees of STIE Nobel Indonesia. This research has been tested through four standards of the validity, namely credibility, transferability, dependability, and confirmability.

\section{Results}

\subsection{The Core Competence of Entrepreneurship}

Through the implementation of curriculum development needs analysis, there have obtained core competencies of entrepreneurship that are divided into four core competencies. The first is the skill in learning and growth perspective. The second is the skill in internal business process perspective. The third is the skill in the customer perspective. The fourth is the skill in financial perspective. 
Table 1. Skills in learning and growth perspective

\begin{tabular}{llll}
\hline No & skill Items & No & skill Items \\
\hline 1 & business knowledge & 18 & simple thinking \\
2 & understand the business well & 19 & Pursuing opportunities with high discipline \\
3 & Management capabilities & 20 & ready to work hard \\
4 & Mastery of technology & 21 & immediately rise when falling \\
5 & Global oriented, & 22 & strong will to survive \\
6 & strategic understanding & 23 & confidence \\
7 & Financial knowledge & 24 & discipline \\
8 & Managerial capability & 25 & commitment \\
9 & The ability to seek new opportunities & 26 & the spirit of leadership \\
10 & Smart in taking opportunities & 27 & creative \\
11 & Skills in organizing priority scale & 28 & innovative \\
12 & Human resource management & 29 & independent \\
13 & The ability to obtain working capital & 30 & Realistic with a strong will \\
14 & accuracy in selecting business & 31 & having a particularity \\
15 & time management & 32 & Diverse skills \\
16 & Tenacity and sincerity & 33 & Understanding of government regulations \\
17 & Problem solving & & \\
\hline
\end{tabular}

The Table 1 shows that there are 33 basic competencies that should be maintained by an entrepreneur or someone who has the interest to become an entrepreneur. This input is very important and is very valuable information for the university in preparing materials related to the basic competence of entrepreneurship.

Table 2. Skills in internal business process perspective

\begin{tabular}{llll}
\hline No & skill Items & No & skill Items \\
\hline 1 & Appropriate production strategy & 5 & Able to make changes \\
2 & Good process & 6 & Improving knowledge continuously \\
3 & Focus on core business & 7 & technology utilization \\
4 & Focus on execution & 8 & distribution network \\
\hline
\end{tabular}

Table 2 shows that there are 8 skills that are grouped into in the management of business processes. The skills are very important to be owned by an entrepreneur in managing its business. Good operational management will determine the results (output product) so that the product can be accepted by the market because a high-quality process produces it. 
Table 3. Skills in customer perspective

\begin{tabular}{llll}
\hline No & skill Items & No & skill Items \\
\hline 1 & Business Ethics & 8 & The challenges of the market and marketing \\
2 & understanding others & 9 & competition \\
3 & not selfish & 10 & consumer challenges \\
4 & communication skills & 11 & Provide total solutions to customers \\
5 & Establish good communication & 12 & Oriented to customers \\
6 & ability to negotiate & 13 & Attractive promotional programs \\
7 & cooperation & 14 & Observing market competition \\
\hline
\end{tabular}

Table 3 shows that there are 14 skills in the customer perspective. Those skills are very important to be owned by an entrepreneur because the position of customers currently occupies a very important position in the business world especially if it is associated with the necessity for every effort to be oriented to customer satisfaction.

Table 4. Skill in financial perspective

\begin{tabular}{llll}
\hline No & skill Items & No & skill Items \\
\hline 1 & Dare to take risks & 7 & results-oriented \\
2 & Able to read circumstances & 8 & Financial Governance \\
3 & Future-oriented & 9 & Careful planning \\
4 & Marketable price & 10 & Proper budgeting \\
5 & analytical skill & 11 & avoiding wastage \\
6 & Trying to get achievement & & \\
\hline
\end{tabular}

The Table 4 shows that there are 11 skills that are very important in the financial perspective. These skills are very important to be owned by an entrepreneur. The financial perspective is one of the main perspectives that become parameters of success from a business perspective. Therefore, it is no wonder if the size of the success of a business in the traditional performance appraisal system is examined from the success in achieving the financial perspective.

\subsection{The Formulation of Competence}

Further analysis is conducted to determine the competency groups and formulate them. The competencies are classified into three groups of competencies, namely the core competencies, supporting competencies and other competencies that are important to be owned by the college graduates. Furthermore, the competence groups are formulated into four skills by using balanced scorecard approach, namely skill in learning and growth perspective, skill in internal business process perspective, skill in customer perspective, and skill in financial perspective. 
Table 5. The determination of the competence groups

\begin{tabular}{|c|c|c|}
\hline $\begin{array}{l}\text { competence } \\
\text { groups }\end{array}$ & formulation o & competence \\
\hline \multirow{6}{*}{$\begin{array}{l}\text { Core } \\
\text { competence }\end{array}$} & \multirow{3}{*}{$\begin{array}{l}\text { learning and } \\
\text { growth }\end{array}$} & Having an entrepreneurial spirit that is the basis of independence in the work \\
\hline & & Having a strategic ability in business management and entrepreneurship \\
\hline & & $\begin{array}{l}\text { Being able to understand and implement the basics of general management in } \\
\text { organizations and business }\end{array}$ \\
\hline & $\begin{array}{l}\text { internal } \\
\text { business } \\
\text { process }\end{array}$ & $\begin{array}{l}\text { Being able to understand and implement the basics of operational management } \\
\text { in organizations and business }\end{array}$ \\
\hline & customer & $\begin{array}{l}\text { Being able to understand and implement the basics of marketing management } \\
\text { in business management and entrepreneurship }\end{array}$ \\
\hline & finance & $\begin{array}{l}\text { Being able to understand and implement the basic principles of financial } \\
\text { management in business and entrepreneurship }\end{array}$ \\
\hline \multirow{4}{*}{$\begin{array}{l}\text { Supporting } \\
\text { competence }\end{array}$} & $\begin{array}{l}\text { learning and } \\
\text { growth }\end{array}$ & $\begin{array}{l}\text { Having a creative and innovative spirit in the work } \\
\text { Being able to adapt to changes and developments in technology and } \\
\text { information }\end{array}$ \\
\hline & $\begin{array}{l}\text { internal } \\
\text { business } \\
\text { process }\end{array}$ & $\begin{array}{l}\text { Being able to identify, analyze, and take managerial decisions on issues of } \\
\text { business processes and entrepreneurship }\end{array}$ \\
\hline & customer & $\begin{array}{l}\text { Being able to identify, analyze, and take managerial decisions on marketing } \\
\text { issues in business and entrepreneurship }\end{array}$ \\
\hline & finance & $\begin{array}{l}\text { Being able to identify, analyze and take managerial decisions on financial } \\
\text { issues in business and entrepreneurship }\end{array}$ \\
\hline \multirow{4}{*}{ others } & $\begin{array}{l}\text { learning and } \\
\text { growth }\end{array}$ & $\begin{array}{l}\text { Having an entrepreneurial spirit and sensitivity towards issues of business and } \\
\text { entrepreneurship and having a fighting spirit and togetherness in advancing the } \\
\text { welfare of the wider community with reference to the value of the local cultural } \\
\text { and religious norms of society }\end{array}$ \\
\hline & $\begin{array}{l}\text { internal } \\
\text { business } \\
\text { process }\end{array}$ & $\begin{array}{l}\text { Being able to make changes and continuous improvement in processes or } \\
\text { business and entrepreneurial activities, which are directed at the orientation in } \\
\text { fulfilling the needs, desires and expectations of the wider community }\end{array}$ \\
\hline & customer & $\begin{array}{l}\text { Being able to establish good communication by upholding moral and ethical } \\
\text { values in accordance with religious and cultural norms of society }\end{array}$ \\
\hline & finance & $\begin{array}{l}\text { Always oriented to the results and the best achievements in the implementation } \\
\text { of business and entrepreneurship }\end{array}$ \\
\hline
\end{tabular}

\subsection{Distribution of Subjects Based on the Predetermined Competencies}

Based on the results of the competence mapping that has been conducted, the next step is inserting the competence items into the subjects that are relevant by paying attention to various aspects. Therefore, these items can indeed be translated through the subjects that will be taught. This step is performed through intensive discussions involving teachers, management, and foundations by using FGD media. In the discussion, in-depth study of the competence items that has been chosen is conducted. It is expected that there is a harmony that will greatly affect the success or failure of the learning process.

\subsubsection{Subjects for Competence in Basic Business Skills (Learning and Development)}

Learning to achieve competence of basic business skills was an important milestone in changing the mindset of the students. In accordance with the results of this research, there are thirty-four items of skills that become basic skills that should be owned by the prospective entrepreneurs. These items must be taught or can be translated through the subjects that will be taught to the students. Therefore, the goal to be able to change the mindset of students into the mindset of entrepreneurs can reach the target. Based on the results of the focus group discussion, 
the subjects directed to provide basic learning business skills are produced as presented in the Table 6 below.

Table 6. Distribution of Subjects on Learning and Development Perspective

\begin{tabular}{|c|c|c|}
\hline skill group & skill Items & Subjects \\
\hline \multirow{36}{*}{$\begin{array}{ll}\text { Learning } & \text { and } \\
\text { Development } & \\
\text { (Basic skills of } \\
\text { business) }\end{array}$} & \multirow{4}{*}{ business knowledge } & Introduction to Business \\
\hline & & Entrepreneurship \\
\hline & & microeconomics \\
\hline & & macroeconomics \\
\hline & \multirow{4}{*}{ understand the business well } & microeconomics \\
\hline & & macroeconomics \\
\hline & & Introduction to Business \\
\hline & & Entrepreneurship \\
\hline & \multirow[b]{2}{*}{ Management capabilities } & Introduction to Management \\
\hline & & $\begin{array}{l}\text { Management of Small and Medium Enterprises } \\
\text { and Cooperatives }\end{array}$ \\
\hline & Mastery of technology & Introduction to Information Technology \\
\hline & \multirow{2}{*}{ Global oriented } & Introduction to Business \\
\hline & & Business English \\
\hline & strategic understanding & Introduction to Management \\
\hline & Financial knowledge & Introduction to Accounting \\
\hline & Managerial capability & Introduction to Management \\
\hline & \multirow{2}{*}{$\begin{array}{l}\text { The ability to seek new } \\
\text { opportunities }\end{array}$} & Business Plan \\
\hline & & Feasibility Study \\
\hline & Smart in taking opportunities & Business Mathematics \\
\hline & $\begin{array}{l}\text { Skills in organizing priority } \\
\text { scale }\end{array}$ & Business statistics \\
\hline & Human resource management & Human Resource Management \\
\hline & The ability to obtain working & Business Plan \\
\hline & capital & Feasibility Study \\
\hline & ocourocy in selecting bucinecs & Business Plan \\
\hline & aceuracy int setecting ousmess & Feasibility Study \\
\hline & time management & Leadership \\
\hline & Tenacity and sincerity & Leadership \\
\hline & Problem solving & Leadership \\
\hline & simple thinking & Leadership \\
\hline & $\begin{array}{l}\text { Pursuing opportunities with } \\
\text { high discipline }\end{array}$ & Leadership \\
\hline & ready to work hard & Leadership \\
\hline & immediately rise when falling & Leadership \\
\hline & strong will to survive & Leadership \\
\hline & confidence & Leadership \\
\hline & discipline & Leadership \\
\hline & commitment & Leadership \\
\hline
\end{tabular}




\begin{tabular}{ll}
\hline the spirit of leadership & Leadership \\
creative & Business creation \\
& Design Thinking and innovation \\
innovative & Business creation \\
independent & Design Thinking and innovation \\
Realistic & Leadership \\
having a particularity & Leadership \\
& Business creation \\
Diverse skills & Design Thinking and innovation \\
government regulations & Business creation \\
& Design Thinking and innovation \\
\end{tabular}

4.3.2 The Subjects for the Competence in the Skills of Handling Business Processes (Internal Business Process)

The results of this research show that there are ten skill items in handling business process that should be owned by prospective entrepreneurs. These items must be taught or can be translated through the subjects that will be taught to the students. Therefore, the goal to be able to create graduates who have skills in conducting business in the field can be realized. Based on the results of FGD, there have been produced some subjects directed to be able to provide learning skills such as handling business processes as presented in the Table 7 below.

Table 7. Distribution of subjects in business process perspective

\begin{tabular}{lll}
\hline Skill group & Skill Items & Subjects \\
\hline & Appropriate production & operational Research \\
strategy & Production Management \\
& Good process & Total Quality Management \\
& & Managing Service Operation \\
& Focus on core business & Enterprises and Cooperatives \\
& & Strategic Management \\
Internal Business Process Perspective & Focus on execution & Strategic Management \\
& Able to make changes & Total Quality Management \\
& Improving knowledge & Total Quality Management \\
& continuously & Business computer applications \\
& & Management Information System \\
& technology utilization & E-Business \\
& distribution network & Supply Chain Management \\
\hline
\end{tabular}

\subsubsection{The Subjects for Competence in Communication and Marketing Skills (Customers)}

The subjects to teach students to have the skills of communication and marketing is the subjects that are oriented how they can do a good interaction with the public (consumers) especially associated with the purpose of business marketing. This capability is very important because there is a thought that every effort should be oriented to the customer based on the fact that consumers are now more enlightened and have freedom in an effort to meet their needs, desires and expectations.

In addition, the goal of mastering communication and marketing skills is also directed to provide supplies 
internally how the students can have a good and interesting personal. Therefore, they can be easy to be accepted by the community because business is not only about competitor but also partner who can be invited to collaborate in developing and building business management. Based on the needs, the relevant subjects are chosen through FGD to achieve the goal of student achievement of competence as presented in Table 8 as follows.

Table 8. Distribution of subjects on the customer perspective

\begin{tabular}{|c|c|c|}
\hline skill group & Skill Items & Subjects \\
\hline $\begin{array}{l}\text { Customer (Marketing and } \\
\text { Business Communication) }\end{array}$ & 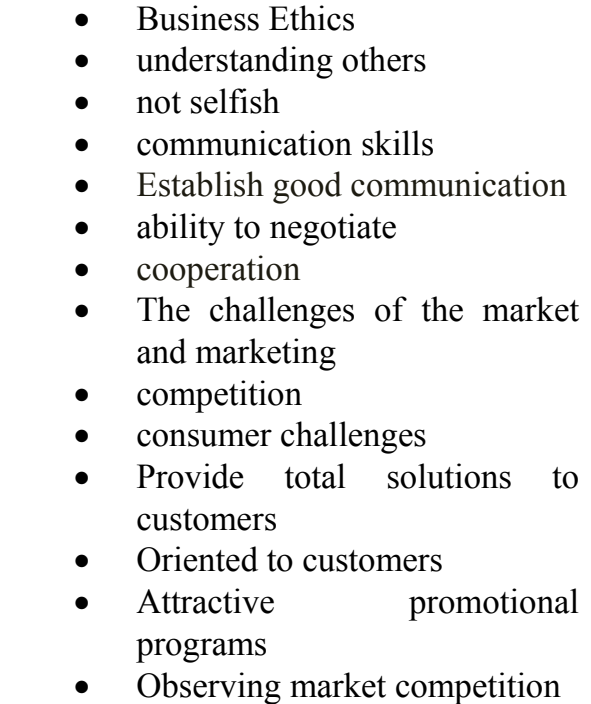 & $\begin{array}{l}\text { - } \text { Law and Business Ethics } \\
\text { - } \text { Personality Development } \\
\text { - } \begin{array}{l}\text { Negotiations and } \\
\text { Business Communication }\end{array} \\
\text { - Marketing Management } \\
\text { - The marketing strategy of } \\
\text { - } \text { Oreative industries } \\
\text { - Sperations management } \\
\text { services }\end{array}$ \\
\hline
\end{tabular}

\subsubsection{The Subjects for Competence in Financial Structuring}

Competence in terms of financial arrangements is important to be owned by the prospective entrepreneurs because the financial perspective is a measure to determine whether a business is advanced and retreated. In addition, financial situation also will determine whether the business will be developed or closed. Therefore, an understanding of management becomes mandatory for prospective entrepreneurs. Through the results of this study, there have been found eight items of financial arrangements issues that should be owned by the prospective entrepreneurs as presented in the Table 8 as follows.

Table 9. Distribution of subjects in financial perspective

\begin{tabular}{|c|c|c|}
\hline Skill group & Skill Items & Subjects \\
\hline Finance & $\begin{array}{ll}\text { - } & \text { Dare to take risks } \\
\text { - } & \text { Able to read circumstances } \\
\text { - } & \text { Future-oriented } \\
\text { - } & \text { Marketable price } \\
\text { - } & \text { analytical skill } \\
\text { - } & \text { Trying to get achievement } \\
\text { - } & \text { results-oriented } \\
\text { - } & \text { Financial Governance } \\
\text { - } & \text { Careful planning } \\
\text { - } & \text { Proper budgeting } \\
\text { - } & \text { avoiding wastage }\end{array}$ & $\begin{array}{l}\text { - } \text { Risk Management } \\
\text { - } \text { Managerial accounting } \\
\text { - } \text { Taxation } \\
\text { - } \text { Analysis of financial statements } \\
\text { - } \text { Budgeting business } \\
\text { - Accounting fees }\end{array}$ \\
\hline
\end{tabular}

\subsection{Curriculum Structure}

The curriculum structure for each semester is a curriculum structure that is associated with a sequence of administration subjects. These sequences have been considered so that the purpose of the whole learning process can be achieved in accordance with the predetermined purpose. In accordance with this study, the structure of the curriculum for each semester is set with the sequences which refer to the principle of balanced scorecard as 
illustrated in the following figure.

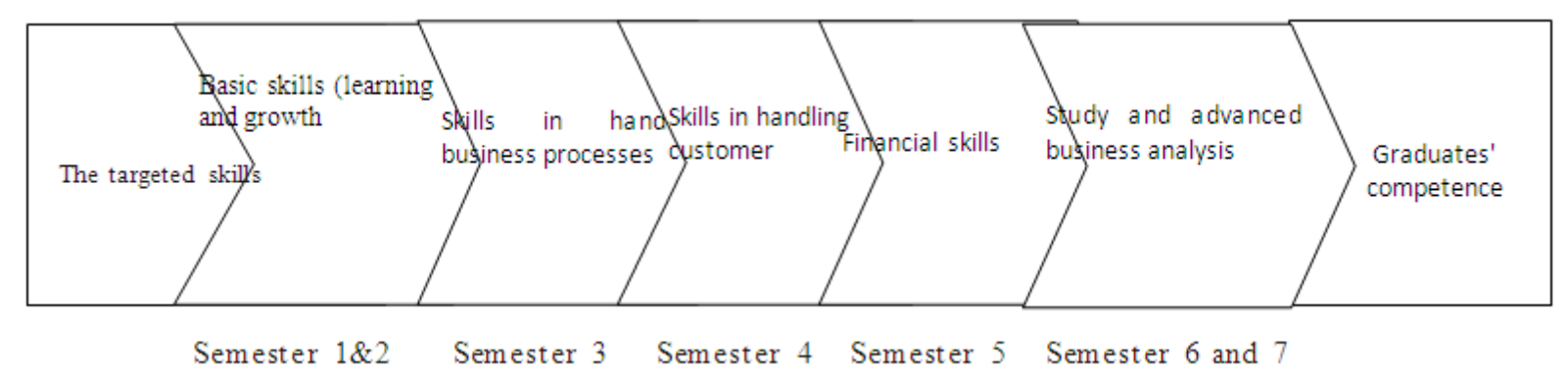

Figure 2. The curriculum structure for each semester using the balanced scorecard approach

The distribution of the subjects according to the curriculum structure for each semester in detail is described in the Table 10 as follow:

Table 10. Distribution of the Subjects for Each Semester before and after the Curriculum Development Semester I

\begin{tabular}{|c|c|c|c|c|c|}
\hline \multicolumn{3}{|c|}{ BEFORE CURRICULUM DEVELOPMENT } & \multicolumn{3}{|c|}{ AFTER CURRICULUM DEVELOPMENT } \\
\hline No & Subjects & $\begin{array}{l}\text { University } \\
\text { Credit Unit }\end{array}$ & No & Subjects & $\begin{array}{l}\text { University } \\
\text { Credit Unit }\end{array}$ \\
\hline 1 & $\begin{array}{l}\text { Introduction } \\
\text { accounting }\end{array}$ & 4 & 1 & religious education & 2 \\
\hline 2 & $\begin{array}{l}\text { Introduction } \\
\text { Management }\end{array}$ & 3 & 2 & $\begin{array}{l}\text { Pancasila (Five Principles) } \\
\text { and Citizenship Education }\end{array}$ & 3 \\
\hline 3 & microeconomics & 3 & 3 & Introduction to Business & 3 \\
\hline 4 & Business Mathematics & 3 & 4 & Introduction to Management & 3 \\
\hline 5 & $\begin{array}{l}\text { Business } \\
\text { communication }\end{array}$ & 3 & 5 & Business Mathematics & 3 \\
\hline 6 & religious education & 2 & 6 & Introduction to accounting & 3 \\
\hline \multirow[t]{3}{*}{7} & $\begin{array}{ll}\text { Introduction } & \text { to } \\
\text { Entrepreneurship }\end{array}$ & 3 & 7 & $\begin{array}{l}\text { Design Thinking and } \\
\text { Innovation }\end{array}$ & 2 \\
\hline & & 21 & 8 & Business English I & 2 \\
\hline & & & & microeconomics & 3 \\
\hline \multicolumn{2}{|c|}{$\begin{array}{l}\text { Total of University Credit } \\
\text { Unit }\end{array}$} & & \multicolumn{2}{|c|}{ Total of University Credit Unit } & 24 \\
\hline \multicolumn{6}{|c|}{ mester II } \\
\hline \multicolumn{3}{|c|}{ BEFORE CURRICULUM DEVELOPMENT } & \multicolumn{3}{|c|}{ AFTER CURRICULUM DEVELOPMENT } \\
\hline No & Subjects & $\begin{array}{l}\text { University } \\
\text { Credit Unit }\end{array}$ & No & Subjects & $\begin{array}{l}\text { University } \\
\text { Credit Unit }\end{array}$ \\
\hline 1 & macroeconomics & 3 & 1 & $\begin{array}{l}\text { Introduction to Information } \\
\text { Technology }\end{array}$ & 3 \\
\hline 2 & Business statistics & 4 & 2 & macroeconomics & 3 \\
\hline 3 & $\begin{array}{l}\text { Applied business } \\
\text { computing }\end{array}$ & 4 & 3 & $\begin{array}{ll}\text { Human } & \text { Resource } \\
\text { Management } & \end{array}$ & 3 \\
\hline 4 & Bahasa Indonesia & 2 & 4 & Business statistics & 3 \\
\hline 5 & English I & 3 & 5 & Business English II & 2 \\
\hline
\end{tabular}




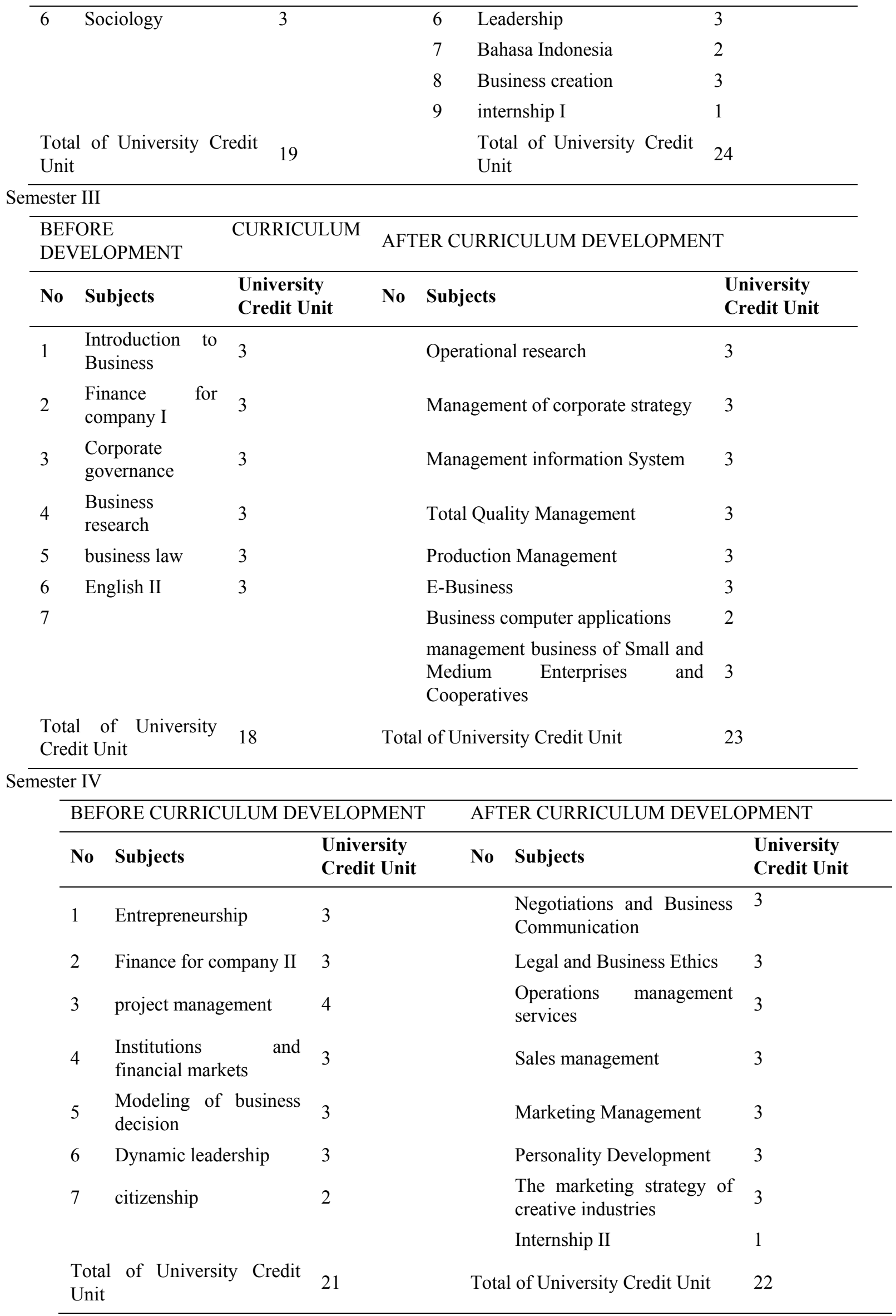


Semester V

\begin{tabular}{|c|c|c|c|c|c|}
\hline \multicolumn{3}{|c|}{ BEFORE CURRICULUM DEVELOPMENT } & \multicolumn{3}{|c|}{ AFTER CURRICULUM DEVELOPMENT } \\
\hline No & Subjects & $\begin{array}{l}\text { University } \\
\text { Credit Unit }\end{array}$ & No & Subjects & $\begin{array}{l}\text { University } \\
\text { Credit Unit }\end{array}$ \\
\hline 1 & managerial accounting & 4 & & Risk Management & 2 \\
\hline 2 & $\begin{array}{l}\text { Operations management } \\
\text { and production }\end{array}$ & 4 & & managerial accounting & 3 \\
\hline 3 & Marketing Management & 4 & & $\begin{array}{l}\text { Corporate Financial } \\
\text { Management }\end{array}$ & 3 \\
\hline 4 & Sales management & 4 & & Accounting fees & 3 \\
\hline 5 & organizational behavior & 3 & & $\begin{array}{l}\text { Analysis of financial } \\
\text { statements }\end{array}$ & 3 \\
\hline 6 & & & & taxation & 3 \\
\hline \multirow[t]{2}{*}{7} & & & & Budgeting business & 3 \\
\hline & & & & $\begin{array}{l}\text { Financial } \\
\text { Management }\end{array}$ & 3 \\
\hline \multicolumn{2}{|c|}{$\begin{array}{l}\text { Total of } \\
\text { University Credit Unit }\end{array}$} & 19 & \multicolumn{2}{|c|}{$\begin{array}{l}\text { Total of } \\
\text { University Credit Unit }\end{array}$} & 23 \\
\hline
\end{tabular}

Semester VI

\begin{tabular}{lll}
\hline BEFORE & CURRICULUM & AFTER CURRICULUM DEVELOPMENT \\
DEVELOPMENT & & \\
\hline
\end{tabular}

\begin{tabular}{|c|c|c|c|c|c|}
\hline No & Subjects & $\begin{array}{l}\text { University } \\
\text { Credit Unit }\end{array}$ & No & Subjects & $\begin{array}{r}\text { University } \\
\text { Credit Unit }\end{array}$ \\
\hline 1 & $\begin{array}{l}\text { Analysis of financial } \\
\text { statements }\end{array}$ & 4 & & $\begin{array}{l}\text { Business Plan } \\
\text { Feasibility Study }\end{array}$ & 3 \\
\hline 2 & $\begin{array}{l}\text { The development of } \\
\text { entrepreneurial skills }\end{array}$ & 3 & & $\begin{array}{l}\text { Business practices and } \\
\text { entrepreneurship }\end{array}$ & 4 \\
\hline 3 & $\begin{array}{ll}\text { Human } & \text { Resource } \\
\text { Management } & \end{array}$ & 4 & & $\begin{array}{l}\text { subjects concentration ( } 3 \\
\text { optional subjects) }\end{array}$ & 9 \\
\hline 4 & crisis Management & 3 & & Business research & 3 \\
\hline 5 & Business Ethics & 3 & & Internship III /KKN-PPM & 2 \\
\hline 6 & $\begin{array}{l}\text { International business } \\
\text { management }\end{array}$ & 3 & & & \\
\hline $\begin{array}{l}\text { Tota } \\
\text { Unit }\end{array}$ & of University Credit & 20 & Tota & of University Credit Unit & 21 \\
\hline
\end{tabular}

Semester VII

\begin{tabular}{llllllll}
\hline \multicolumn{2}{l}{ BEFORE CURRICULUM DEVELOPMENT } & \multicolumn{3}{l}{ AFTER CURRICULUM DEVELOPMENT } \\
\hline No & Subjects & University & Credit & No & Subjects & & \multicolumn{2}{l}{$\begin{array}{l}\text { University } \\
\text { Unit }\end{array}$} & Credit \\
\hline & $\begin{array}{l}\text { Research } \\
\text { seminar }\end{array}$ & proposal & 2 & & $\begin{array}{l}\text { Research } \\
\text { seminar }\end{array}$ & proposal & 2 \\
\hline
\end{tabular}




\begin{tabular}{lllll}
\hline $\begin{array}{l}\text { research result } \\
\text { seminar }\end{array}$ & 2 & \multicolumn{1}{c}{$\begin{array}{l}\text { research } \\
\text { seminar }\end{array}$} & result & 2 \\
$3 \quad$ Thesis & 4 & Thesis & 4 \\
Total of University Credit & 8 & $\begin{array}{l}\text { Total of University Credit } \\
\text { Unit }\end{array}$ & 8 \\
Unit & & Unit & \\
\hline
\end{tabular}

\section{Discussion}

Based on this research, it is known that there are some basics skills of entrepreneurship that should be possessed by someone who is interested to become entrepreneurs. Mastering these skills would have a great contribution to the sustainability of his or her business whether the business will continue to develop or not develop at all. Hence, it is important to have a base and a strong planning, information related to the basic skills of entrepreneurship. Those skills should become the foundation on how to build the entrepreneurial spirit and character to be delivered and studied in universities that provide entrepreneurship education.

The facts at universities in Indonesia, especially in Makassar illustrate that teaching entrepreneurship conducted by universities do not have a clear pattern sequences yet. There has no an integrative teaching that explains the detailed steps to teach entrepreneurship ranging from business initial idea, establishment and implementation. Some subjects about how to handle customer and financial issues can be integrated with other subjects as extra subjects. The integration will give great significance in the formation of scientific entrepreneurship for students. For example, teaching about the business management. It can be integrated with financial management issues in the subjects such as financial management, accounting and financial statement analysis. Likewise, business management related to the consumer can be integrated with the problems of marketing management, product quality and other marketing strategies. Integration can help the students to learn the integrated sciences and link them with the business that will be conducted in the future.

Balanced scorecard has provided a mapping that the success of a business can be viewed from the achievement of performance on four business perspectives, namely (1) financial perspective, (2) customer perspective, (3) internal business process perspective, and (4) learning and growth perspective. Based on the balanced scorecard views, each perspective has integrative relationship as causal relationship between one perspectives to another perspective. The relationship among the perspectives simultaneously will direct the company to achieve the planned goals. This pattern is inspired of how entrepreneurship should be studied, namely how an understanding of business and business will be developed (learning and growth perspective), how to learn good business process that will produce a quality product (business process perspective). It is continued with how to study the market, and the customer (customer perspective) and how to learn financial management, investment and re-investment (the financial perspective).

In this study, the patterns are translated into the provision of some integrated courses. The first is the subjects related to the skills in the learning and growth perspective taught in semester 1 and 2 . The second is the subjects related to the skills for the business process taught in semester 3 . The third is the subjects related to the skills in handling the customer taught in semester 4 . The fourth is the subjects related to the financial management skills taught in semester 5 . The fifth is the additional skills related to continued business development taught in semester 6.

\section{Conclusion}

In this research, the balanced scorecard is used as a strategic tool in mapping the curriculum in the development of entrepreneurship-based curriculum in STIE Nobel Indonesia. Through needs analysis for curriculum development involving all stakeholders in STIE Nobel Indonesia, it has produced entrepreneurship competencies that are classified into the four major skills in accordance with the principle of the balanced scorecard. The skills are the main data in the curriculum development process that includes skill in learning and growth perspective, skill in internal business process perspective, skill in customer perspective, and skill in financial perspective. The skills are then translated into entrepreneurship subjects as a result of entrepreneurship-based curriculum development in this study.

This research has resulted in the curriculum structure with the distribution of subjects for each semester and its implementation is based on the concept of the balanced scorecard. The subjects to teach skills in learning and growth perspective are taught in semester I and semester II. The next, the subjects to teach skills in business 
process perspective are taught in semester III. The subjects to teach skills of customer perspective are taught in semester IV. The subjects to teach skills in financial perspective are taught in semester V. In semester VI, there will be taught the subjects for advanced business skills. The last, semester VII is the last lecture process which is concentrated for students to conduct research and prepare the final project (thesis).

\section{References}

Azizi, F., Behzadian, M., \& Afshari, A. J. (2012). Which Perspectives in The balanced Scorecard are Appropriate For The Universities? European Journal of Scientific Research, 74(2), 164-175. European Publishing. Inc.

Borg,W. R., \& Gall, M. D. (1989). Educational Research: An Introduction (5th ed.). New York: Longman.

Bygrave, W. D. (1994). The Portable MBA in Entrepreneurship. John Willey \& Sons. Inc. New York.

Chandler, A. D. Jr. (1962). Strategy and Structure: Chapters in the History of the American Industrial Enterprise. Cambridge, MA: MIT Press

Chen, S. H., Yang, C. C., \& Shiau, J. Y. (2006). The Application of Balanced Scorecard in the Performance Evaluation of Higher Education. The TQM Magazine, 18(2), 190-205. http://dx.doi.org/10.1108/09544780610647892

Cullen, J., Joyce, J., Hassall, T., \& Broadbent, M. (2003). Quality in Higher Education. From Monitoring to Management Quality Assurance in Higher Education, 11(1), 30-34.

Daryush, F., Mehran, N., \& Heydar, M. (2008). Balanced Scorecard Application In Universities and Higher Education Institute. Implementation Guide in an Iranian Context. Economic and Administrative Analysis series. Bucharest: University of Bucharest.

David, F. R. (2009). Manajemen Strategis. Salemba Empat Jakarta.

Deborah, F. B. (2009). Successful Application of the Balanced Scorecard in Higher Education. Journal of Education for Business, 84(5), 275-282. http://dx.doi.org/10.3200/JOEB.84.5.275-282

Hamid, S., Yu, M. L., \& Soo, H. P. (2007). Measuring the performance and excellence of academicians through the e-Balanced scorecard (e-BSC). In 9th IBIMA Conference information management in modern organizations, 4-6 January 2008. Marrakech, Morocco.

Hamid, S., Yu, M. L., Soo, H. P., \& Ijab, M. T. (2008). Using e-Balanced Scorecard in Managing the Performance and Excellence of Academicians. Pacific Asia Conference on Information System (PA-CIS 2008) on July 3-7 2008. Suzhou, China.

Hoffecker, J., \& Goldenberg, C. (1994). Using the balanced scorecard to develop companywide performance measures. Journal of Cost Management, 8(3), 5-17.

Hussain, A., Dogar, H., Azeem, M., \& Shakoor, A. (2011). Evaluation of Curriculum Development Process. International Journal of Humanities and Social Science, 1(14).

Indriyanti, S. (2012). Implementing Balanced Scorecard in Higher Education management. Case Study: Hasanuddin University of Indonesia. International Journal of business and social Science, 3(18).

Kaplan, R. S., \& Norton, D. P. (1992). The Balanced scorecard-measures that drive Performance. Harvard Business Review, (Summer), 123-145.

Kaplan, R. S., \& Norton, D. P. (1996). Using the Balanced scorecard as a strategic management system. Harvard Business Review (January-February), 1-13.

Kaplan, R. S., \& Norton, D. P. (2001). The strategy-focused organization: How balanced scorecard companies thrive in the new business environment. Boston, MA: Harvard Business School Press.

Karathanos, D., \& Karathanos, P. (2005). Applying the balanced scorecard to education. Journal of Education for Business (March/April), 222-231. http://dx.doi.org/10.3200/JOEB.80.4.222-230

Kettunen, J. (2004). The strategic evaluation of regional development in higher education. International journal of assessment \& evaluation in Higher Education, 29(3). Carfax Publishing, Taylor \& Francis Group.

Lincoln, Y. S., \& Egon, G. G. (1987). Naturalistic Inquiry. SAGE Publication Inc.

Maisel, L. S. (1992). Performance Measurement: The Balanced Scorecard Approach. Journal of Cost Management, 6(2), 47-52.

Meredith, G. G. (1989). Kewirausahaan Teori dan Praktek. Jakarta. Hastama. 
Musselman, A. V. (1989). Introduction to Modern Business. New Jersey.

Newing, R. (1994). Benefits ofa Balanced Scorecard. Accountancy, 114(1215), 52-53.

Niven, P. R. (2002). Balanced Scorecard Step by Step. John Wiley \& Sons. New York. NY.

Ohmae, K. (1990). The Borderless World Power and Strategy in the Interlinked Economy. Copy Right McKinsey \& Company Inc.

Porter, M. E. (1996). Strategi Bersaing: Teknik Menganalisis Industri dan Pesaing. Erlangga, Jakarta.

Potnoy, L. M., Rust, V. D., \& Bagley, S. S. (2010). Higher Education Policy and the Global Competition Phenomenon. 17th Fifth Avenue. New York. United States Palgrave. Macmillan a Division of ST Martin. Press LLC.

Rompho, N. (2012). Building the Balanced Scorecard for University Case Study: The University in Thailand. Retrieved from http://WWW.online.niu.edu

Ruben, D. B. (1999). Toward balanced Scorecard for Higher Education: Rethinking the college and University Excellence Indicators Framework. Higher Education. Retrieved from http://www.qei.rutgers.edu

Sherman, W. R. (2007). In Search Of an itegrative theme for The Undergraduate business Curriculum. Journal of college teaching \& Learning, 4(12).

Smith, B. D., \& Harold, D. F. (2007). Developing an Integrated Curriculum Using the Balanced Scorecard. Retrieved from http://citeseerx.ist.psu.edu/viewdoc/download=10.1.1.199.82

Stewart, A. C., \& Carpenter-Hubin, J. (2001). The balanced scorecard, beyond reports and rankings. Planning for Higher Education, 29(2), 37-42.

Taba, H. (1962). Curriculum Development: Theory and Practice. New York. Brace Word. Inc.

Tilaar, H. A. R. (2002). Perubahan Sosial Pendidikan: Pengantar Pedagogik Transformatif Untuk Indonesia. Jakarta: Penerbit Gramedia.

Umashankar, V., \& Dutta, K. (2007). Balanced scorecards in managing higher education institutions: An Indian perspective. International Journal of Educational Management, 21(7), 54-67. http://dx.doi.org/10.1108/09513540710716821

Yek, T. M., Penney, D., \& Seow. A. C. H. (2007). Using Balanced Scorecard to Improve Quality Performance of Vocational Education and training (VET): a Case study In Singapore. AARE 2007. Conference. November 22-29 Fremantle. Australia.

\section{Copyrights}

Copyright for this article is retained by the author(s), with first publication rights granted to the journal.

This is an open-access article distributed under the terms and conditions of the Creative Commons Attribution license (http://creativecommons.org/licenses/by/3.0/). 